\title{
Does Indonesia's Corruption Eradication Commission (KPK) in Spying on People Violate the International Human Rights Laws in Protecting the Right to Privacy?
}

\author{
$1^{\text {st }}$ Agung Ali Fahmi \\ College of Law \\ Universitas Trunojoyo Madura \\ Bangkalan, Indonesia \\ agungalifahmi@gmail.com
}

\author{
$2^{\text {nd }}$ Dodik Pranata Wijaya \\ College of Law \\ Michigan State University \\ Lansing, USA \\ wijayado@msu.edu
}

\begin{abstract}
The corruption has become a serious focus for Indonesia, particularly since the reform of 1998 . Under the Law Number 30 of 2002, the KPK has the authority to spy on people by tapping into their communication lines and records their conversations. By this interception power, the KPK has captured many corruptors in Indonesia. Despite of the KPK's success, several questions arise: Does Indonesia's Corruption Eradication Commission (KPK) in spying on people violate the international human rights laws in protecting the right to privacy? what is the benchmark to determine that the KPK indeed unlawfully? Is the KPK's interception operation consistent with the international human rights principles regarding the right to privacy? For answering those questions, this paper will outline the concept of the right to privacy from several privacy theorists. To determine whether or not the KPK is indeed acting unlawfully, this paper will use the privacy rights theory and the international human rights covenants in examining the right to privacy. The paper argues some of the interception actions done by the KPK, do not comply with the international principles on human rights in electronic surveillance actions. It means Indonesia must improve its laws through adding some articles in order to fully comply with international principles on human rights in electronic surveillance actions.
\end{abstract}

\section{Keywords: KPK, Human Rights, Interception}

\section{INTRODUCTION}

In 2001, the Corruption Perceptions Index ranked 91 countries. Indonesia was number four of the top five countries with levels of corrupted government and public administration in the world, followed by Azerbaijan, Bolivia, Cameroon, Kenya, Uganda, Nigeria and Bangladesh.[1] In 2017, the Corruption Perceptions Index ranked 180 countries by their levels of public sector corruption according to business people and qualified people, using scale of 0 to 100 , with 0 for highly corrupted country and 100 for very clean country. Indonesia was number 95 out of 180 countries.[2] Under the Law Number 30 of 2002 of the Commission for the Eradication of Criminal Acts of Corruption (hereafter UU KPK), KPK has the authority to spy on people by tapping into their communication lines and records their conversations. By this interception power, KPK has captured many corruptors in Indonesia. The number of people getting ensnared by KPK in corruption case, from 2004 to 2017 are 163 Echelons (I, II, III); 145 senates in House of Representative (DPR and DPRD); 127 Regent, Mayor and Deputy positions; 60 Governors; 17 Judges; 15 Commissioners; 7 for The Heads of Ministry or Agency; 25 Ambassadors and 80 officers in several institutions.[3] In earlier two months of 2018, 7 Regents were captured by KPK. [4] Mostly, they were going to run for the 2018 regional Head Election (Pilkada). Laode M. Syarief as KPK Deputy Chairman said that the politic cost in Indonesia is very high. The high cost of politic leads regional head candidates dragged by corruption case.[5] Undoubtedly, the use of wiretapping can be admitted as one of the major ways KPK can uncover many white-color-crimes. Actually, wiretapping is a common way for law enforcers to reveal a case or scandal.

However, in some cases, wiretapping has a risk of abuse of power. On December $16^{\text {th }}, 2005$, that President Bush authorized the National Security Agency (NSA) to conduct unwarranted wiretapping on American citizens. He secretly authorized the NSA to spy on Americans in the United States without the court-approval.[6] The privacy benchmark at international level can be found in the Universal Declaration of Human Rights 1948 (hereinafter UDHR), the UDHR recognized and protected people's right to privacy. Article 12 states: "No-one should be subjected to arbitrary interference with his privacy, family, home or correspondence, nor to attacks on his honor or reputation. Everyone has the right to the protection of the law against such interference or attacks".[7] Not only the UDHR specifically refers to privacy as a right, but also some of the international conventions have recognized that privacy as a right, such as The International Covenant on Civil and Political Rights (hereinafter ICCPR)

which stated this in Article 17, the Convention on the Right of the Child (hereinafter CRC) which states this in Article 16, and also the International Convention on Protection of the Rights of All Migrant Workers and Members of Their Families (hereinafter ICRMW) which states this in Article 14.

Based on those international instruments, several questions inevitably arise; Does Indonesia's Corruption 
Eradication Commission (KPK) in spying on people violate international human rights laws to protect the right to privacy? In addition, the right to privacy might be limited by other rights, such as the right to life or the safety of community. How do international human rights instruments determine if the KPK is spying indeed unlawful? Is the KPK's interception operation consistent with the international human rights principles regarding the right to privacy?

\section{RESEARCH METHODS}

To answer those questions, this paper will outline the concept of the right to privacy from several privacy theorists'. To determine whether or not the KPK is indeed acting unlawfully, this paper will use the privacy rights theory and the international human rights covenants in examining the right to privacy. Lastly, this paper will determine whether Indonesia laws comply with international human rights' principles in international covenants in order to uphold the right of privacy for Indonesian people. These methods also well-known as a normative methods.

\section{RESULTS AND DISCUSSION}

\section{A. The Concept of Privacy}

During the last century, the concept of privacy has played a large role in legal discussion.[8] Some scholars say that the right of privacy is like the right to be left alone.[9] The scholars who expressed that concept are Samuel Warren and Louis Brandeis. In a Harvard Law Review article, they argued that privacy was an emerging right that needed to be recognized. They said that the right to privacy was not something that is found by only looking at the Constitution. But cultural values and new technology also should have a significant role in developing a new understanding of the right. They further noted that "the value of privacy is found not in the right to take the profits arising from publication, but in the peace of mind or the relief afforded by the ability to prevent any publication at all'. [10] Indeed, they also affirmed that violation of privacy was a harm worse than some physical injury.[8] In addition to the rights to be left alone concept, the "limited access" concept has been recognized by several privacy theorists. This might be related to the to be left alone, but not equivalent to solitude.

Solitude is a form of alienation from society. This concept extends far beyond the freedom of government interference, as well as intrusions by the press and others.[11] One of the famous aspects of privacy is that of control over personal information. This concept can be viewed as a limitation access to people's data information which cannot be owned by other people. Several theorists tried to define the extent of what constitutes personal information over which individuals should exercise control, but the more they try the more they find difficulties. For instance, Richard Parker has attempted to define the extent of personal information, he thought is "Privacy is control over when and by whom the various parts of us can be sensed by others". That definition sounds very broad. Daniel J. Solve responds to Parker's concept, by saying "Parker's definition would make most interpersonal contact in society a privacy invasion because it brings unwanted access to the self. Yet, we are frequently seen and heard by others without perceiving it as even the slightest invasion of privacy".[11]

\section{B. The Right to Privacy in Several International Covenants}

In 1946, the Universal Declaration of Human Rights (herafter UDHR) was drafted. The UDHR paved way to the ICCPR and the International Covenant on Economic Social and Cultural Rights (hereafter ICESCR). Those has been an explosion of human rights treaties over the years. Since the UDHR was drafted, it was clear enough that privacy would be guaranteed in one form or another.[12] Through Article 12 The UDHR, it tries to protect the right to privacy of people constructively. The Article 12 of the UDHR stated: "No one shall be subjected to arbitrary interference with his privacy, family, home or correspondence, nor to attacks upon his honor and reputation. Everyone has the right to the protection of the law against such interference or attacks.'"[7] Asbjurn Eide said in his book The Universal Declaration of Human Rights: A Commentary that this article is an umbrella article. They argue that the scope of this article is too broad because it does not only protect for person's privacy but also to his family, home, correspondence even for attacking upon his honor and reputation.[13] However, this paper argues that article 12 does fit in this era. Since the advances in information communication technology are significantly improved, clearly that technologies are vulnerable to electronic surveillance and interception. Amplifying the scope of the right to privacy will prevent people from abuse of power which might have an effect on his family. Even for law enforcement reasons, government should be able to protect the crucial information of the suspects. Government should not expose the suspects' information to the public, because it may cause such a negative effect to people around them.

For example, in Al Amin's corruption case, KPK disseminated the evidence to the public when he was about to hand over 71 million rupiah to someone. KPK also presented to the public the evidence that there was a young lady in the hotel with Al Amin. People believed she was a prostituted-woman.[14] Al Amin became trending topic in his hometown.[15] As a result, Kristina who

the wife of Al-Amin feel ashamed and stressed which resulted in the end of the marital relationship. This paper's point of view is, KPK. in this case already attacked $A l$ Amin's honor and dignity. Even for the law enforcement reasons, KPK should not share the information to the public. All the information they got from their operation should have been viewed and heard for KPK's team only, or when 
KPK brought him to the court. Because everyone who claimed as a criminal shall have the right to be presumed innocent until proved guilty and had final decision from the court.

In the International Covenant on Civil and Political (herafter ICCPR) is a key international human rights treaty which provide a range of protections for civil and political rights. The ICCPR, the UDHR, ICESCR and First Optional Protocol to the International Covenant on Civil on Political Rights (hereafter FOPICCPR) are considered the International Bill of Human Rights.[16] The ICCPR, was adopted by the U.N General Assembly in 1996 and came into force in 1976. At least 167 countries have ratified in December 2013, including Indonesia. Indonesia ratified or acceded in February 23, 2006 and entered to force on May 23, 2006. The ICCPR obligates countries to ratifying the treaty in order to protect and preserve a basic human right of people.[17] One of the human rights that well covered by ICCPR is the right of privacy. At least 2 Articles which discussed about the right of privacy.[18] The right is enshrined in Article 14, and Article 17: “(1) ... when the interest of the private lives of the parties so requires, or to the extent strictly necessary in the opinion of the court in special circumstances where publicity would prejudice the interests of justice..." (2) "Everyone charged with a criminal offence shall have the right to be presumed innocent until proved guilty according to law."[19] Additionally, Article 17 stated: “(1) No one shall be subjected to arbitrary or unlawful interference with his privacy, family, home or correspondence, nor to unlawful attacks on his honor and reputation. (2) Everyone has the right to the protection of the law against such interference or attacks."'[19]

Those covenants aboved, are not only instrument which protect the right of people's privacy. There is convention which deals with the child-spesific needs and rights. Countries that ratified this convention are bound to it by international law and must act in the best interest of the child. Although the CRC was adopted by the UN General Assembly in 1989, it was first available for signature was on January 26, 1990. Indonesia was one of the countries which signed on the first day of this Convention.[20]

In 1972, attemted to protect the rights of migrant workers for the first time. On December $18^{\text {th }}$, 1990, the International Convention on Protection of the Rights of All Migrant Workers (herafter ICRMW) was adopted by the UN General Assembly and entered into force on July $1^{\text {st }},[21]$ 2003. Eight years later, Indonesia ratified this Convention on May 31 ${ }^{\text {st }}$, 2012.[22] The right to privacy in this Convention described in Article 14 which states: "No migrant worker or member of his or her family shall be subjected to arbitrary or unlawful interference with his or her privacy, family, home, correspondence or other communications, or to unlawful attacks on his or her honor and reputation. Each migrant worker and member of his or her family shall have the right to the protection of the law against such interference or attacks..."[23]
Even for disabled people have a protection in international convention such as the Convention on the Rights of Person with Disabilities (hereafter CRPD) which provided in Article 22. "(1) No person with disabilities, regardless of place of residence or living arrangements, shall be subjected to arbitrary or unlawful interference with his or her privacy, family, or correspondence or other types of communication or to unlawful attacks on his or her honor and reputation. Persons with disabilities have the right to the protection of the law against such interference or attacks. (2) States Parties shall protect the privacy of personal, health and rehabilitation information of persons with disabilities on an equal basis with others"'[24]

Sum up, the international community has established such an international standard on the protection of privacy for every element of people, including children, workers, family workers, disability people. Thus, each country is not only obliged to protect the right to privacy for their citizens, but also country should prohibit every violation which against the rights of privacy through the application of laws within a country.

\section{The International Human Rights Principles}

If we look at the international human rights instrument as described above, clearly, Indonesia seems very active in protecting the right of privacy. Indonesia has already ratified the the right of privacy instruments. But, does KPK in spying on people violate international human rights laws protecting the right to privacy? And also, we might think that the right to privacy might be limited by other competing rights. So, to determine if KPK spying is indeed unlawful this section will focus on some principles of the international human right laws. Rights can be divided into two forms, as derogable or non-derogable rights. Article 4 of the ICCPR provides for a derogation power, which means to allow governments to temporarily suspend the application of some rights in the exceptional circumstances.[25] based on Article 4 (2) of the ICCPR the right to privacy constitutes as a derogable rights. Since the right to privacy constitutes as derogable rights, countries might take measures derogating from certain of their obligation under the Covenant, including the prohibition on interference with privacy and attacks on reputation. Such measures might only be taken to the extent strictly required by the exigencies of the situation, provided that such measures are not inconsistent with their other obligations under international law. Moreover, the measures shall not involve discrimination based on race, color, sex, language, religion or social origin. For limitations itself ICCPR does not set out the reasons for which the guarantees in it might be limited. In any event, limitations on privacy must be authorized by law and must not be arbitrary.[26]

Basically, wiretapping or interception is prohibited and violation of people's private zone. However, in certain situation either wiretapping and interception can be justified when used for law enforcement and national security. In 
addition, to be justified of such interception action must be in accordance with international principle concerning the application of human rights that limit the act of interception. The Inter American Court of Human Rights (hereafter IACtHR) and the European Court of Human Rights (hereafter EctHR) also deal with human right violations related to state spying and interception. These principles consist of legality, legitimate aim, necessity and proportionality, safeguards toward illegitimate access, and lastly due process.[27]

\section{The Connection of Human Rightss Principles and KPK}

There are some principles from IACtHR and EcTHR to justify interception act must be in accordance with international principle concerning the application of human rights that limit the act of interception First, is legality; the interception actions by KPK is regulated in Article 12 (1) of the law of KPK and also reinforced by three decisions of Consitutional Court or Mahkamah Konstitusi (MK). Since KPK legally provided by law, this principle KPK is satisfied. Second, Legitimate Aim. This principle emphasizes that this interception or electronic surveillance action should be carried out with legitimate purpose. In Article 12 (1) of the Law of KPK clearly has been given the authority to conduct interception actions with regard to individuals suspected of being linked to a criminal corruption either in the process of investigation or prosecution. Third, Necessity. In this case is the limitation of surveillance measures. This principle attempts to confirms that interception is the last resort in finding information of about for the corruption issue. In Indonesia, there are no articles in laws which state that interception is the last resort. However, the fact that the amount of corruption in Indonesia massive, it could be said that this extraordinary crime surveillance is the last resort. Fourth, is Proportionality; this paper argues that proportionality means the information accessed will be used for the related crime and any unused information will be destroyed or will be returned to the spied-upon person. Moreover, KPK should not publish people's secrets which affect his family's dignity and family's honor. Lastly, Safeguard Against Illegitimate Access; This principle emphasizes the existence of both criminal and civil penalties against parties who use intercepted information in an unauthorized manner. This principle will have the result that all evidence resulting from unlawful interception should be considered as inadmissible evidence. This concept also is not recognized in the law of KPK. Thus, with respect to the interception action which are done by the KPK some of them do not comply with the international principles on human rights in electronic interception action. This means Indonesia must add some articles in order to fully comply with the international principles on human rights in electronic surveillance actions.

\section{CONCLUSION}

Indonesia commonly recognize that corruption as an extra ordinary crime that has to be combated by extra ordinary ways as well. Interception has been determined as the best way to reduce the number of these engaged in corruption, Indonesia is adherence to some international human rights instrument aims to support the basic rights of the people.

The scope of the concept of privacy, in some theorists' perspective has sailed to be properly conceptualized. In addition, the international community recognizes privacy is a fundamental human right which is well-described in several Conventions. This reflects the importance of the right to privacy for every individual in the world, either for adult, children or for people who have disabilities. Some of the interception actions done by the KPK through electronic surveillance actions, do not comply with the international principles on human rights. This means Indonesia must improve its laws through adding some articles in order to fully comply with international principles on human rights in electronic surveillance actions.

\section{REFERENCES}

[1] Transperancy International, “Corruption Perceptions Index 2001," 2001.

[2] Transperancy International, "CORRUPTION PERCEPTIONS INDEX 2017,", 2017.

[3] KATA DATA News and Research, "Ternyata Pejabat Swasta Paling Banyak Tertangkap Korupsi KPK 'It turns out Private Officials Most Caught Corruption KPK,", 2017. [Online]. Available: https://databoks.katadata.co.id/datapublish/2017/06/21/ternyatapejabat-swasta-paling-banyak-tertangkap-korupsi-kpk. [Accessed: 28-Feb-2018]

[4] A. Gabrillin, "Belum Genap 2 Bulan Tahun 2018, Tujuh Kepala Daerah Jadi Tersangka KPK 'Not Even Even 2 Months In 2018, Seven Regional Heads became suspects KPK," Kompas.com, Jakarta, 15-Feb-2018.

[5] "KPK on Many Regional Head Candidates Getting Ensnared by Corruption Cases," Netral English "People Reflection," 2018. [Online]. Available: http://www.en.netralnews.com/news/currentnews/read/18485/kpk.on .many.regional.head.candidates.getting.ensnared.by.corruption.cases. [Accessed: 27-Feb-2018].

[6] J. R. and E. LICHTBLAU, "Bush Lets U.S. Spy on Callers Without Courts," The New York Times, 16-Dec-2005.

[7] The World Health Assembly, "Universal Declaration of Human Rights," Int. J. Hum. Rights, vol. 2, no. 3, pp. 84-88, 1998.

[8] J. H. Moor, "The ethics of privacy Protection," Libr. Trends, vol. 39, no. $1-2$, p. 70, 2004

[9] "Recent Developments in the Right of Privacy," Univ. Chicago Law Rev., vol. 15, No. 4, p. 927, 1948.

[10] S. D. W. \& L. D. Brandeis, "The Right to Privacy," Harv. Law Rev., vol. 4, p. 200, 1890.

[11] D. J. Solove, "Conceptualizing privacy," Calif. Law Rev., vol. 90, no. 4, pp. 1087-1155, 2002.

[12] O. Diggelmann and M. N. Cleis, "How the right to privacy became a human right," Hum. Rights Law Rev., vol. 14, no. 3, pp. 441-458, 2014.

[13] A. R. Asbjørn Eide, Gudmundur Alfredsson, Göran Melander, Lars Adam Rehof, The Universal Declaration of Human Rights: a commentary / edited by Asbjørn Eide [and others]; with the collaboration of Theresa Swinehart. Oslo: Scandinavian University Press, 1992.

[14] “Al-Amin Nasution Dibekuk KPK (Al-Amin Nasution Arrested by 
KPK)," Hukum Online.com, 09-Apr-2008.

[15] R. Hidayat, “Al Amin Nasution Jadi 'Buah Bibir' Warga Jambi (Al Amin Nasution Become Hot Topic in Jambi)," Kompas.com, p. 1, 2008.

[16] F. N. David Weissbrodt, Fionnuala Ni Aolain, joan Fitzpatrick, International HUman Rights: Law, Policy, and Process, 4th ed. Lexis Nexis, 2009.

[17] "THE COVENANT ON CIVIL \& POLITICAL RIGHTS (ICCPR)," $A C L U$, 2014. [Online]. Available: https://www.aclu.org/other/faqcovenant-civil-political-rights-iccpr. [Accessed: 18-Apr-2018].

[18] "Definitions of the right to privacy," Claiming Human Rights Guide to International Procedures Available in Cases of Human Rights Violations in Africa. [Online]. Available: http://www.claiminghumanrights.org/privacy_definition.html. [Accessed: 18-Apr-2018].

[19] United Nations Human Rights, "International Covenant on Civil and Political Rights," United Nations Hum. Rights, no. March, p. 26, 1976.

[20] "Convention on the Rights of the Child," United Treaty Collection, 1989. [Online].

Available: https://treaties.un.org/Pages/ViewDetails.aspx?src=TREATY\&mtds g_no=IV-11\&chapter=4\&lang=en. [Accessed: 18-Apr-2018].

[21] "Protection of the Rights of Migrant Workers," World Heal. Organ., p. $1,2003$.

[22] "International Convention on the Protection of the Rights of All Migrant Workers and Members of their Families," United Treaty Collection, 1990 .

[23] International Convention on the Protection of the Rights of All Migrant Workers and Members of Their Families, no. December. 1990, p. 6.

[24] United Nation, Convention on the Rights of Persons with Disabilities and Optional Protocol. p. 15.

[25] Human Rights Committee, "Absolute rights," Australian Government: Attorney-General's Department, 2001. [Online]. Available:

https://www.ag.gov.au/RightsAndProtections/HumanRights/Humanrightsscrutiny/PublicSectorGuidanceSheets/Pages/Absoluterights.aspx. [Accessed: 19-Apr-2018].

[26] "Privacy and reputation," Australian Government: AttorneyGeneral's Department, 2005. [Online]. Available: https://www.ag.gov.au/RightsAndProtections/HumanRights/Humanrights-

scrutiny/PublicSectorGuidanceSheets/Pages/Privacyandreputation.as px. [Accessed: 09-Apr-2018].

[27] Privacy International, "The Principles on the Application of Human Rights to Communications Surveillance in the Jurisprudance of Regional Human Rights Courts,” 2013. 